\title{
Cikkismertetés: Mi is az „Egy az egészség"?
}

\section{Article review: What is „One Health"?}

\begin{tabular}{ll}
\hline Ismertető: & Vitrai József \\
Ismertetett: & Centers for Disease Control and Prevention. One Health Basics. \\
honlap: & https://www.cdc.gov/onehealth/basics/index.html (Elérve: 2021. 05. 31.) \\
$\begin{array}{l}\text { Kulcsszavak: } \\
\text { Keywords: }\end{array}$ & "Egy az egészség"; környezet; globalizáció; fenntarthatóság \\
\hline
\end{tabular}

Beküldve: 2021. 05. 31., doi: 10.24365/ef.v62i3.6543

\section{IS AZ „EGY AZ EGÉSZSÉG"?}

$\mathrm{Az}$ "Egy az egészség" olyan szemlélet, amely felismeri, hogy az emberek egészsége szorosan összefügg az állatok és a közös környezetünk egészségével, azokkal egységet, egységes egészet alkot. Az "Egy az egészség"-megközelítés nem új keletű, de az utóbbi években egyre fontosabbá vált. Ennek oka, hogy számos tényező megváltoztatta az emberek, állatok, növények és környezetünk közötti kölcsönhatásokat.

Az emberi népesség növekszik, és új földrajzi területekre terjeszkedik, amelynek hatásaként több ember él szoros kapcsolatban vadon élő, valamint haszonállatokkal és háziállatokkal egyaránt. Az állatok fontos szerepet játszanak az életünkben, legyen szó élelemről, rostokról, megélhetésről, utazásról, sportról, oktatásról vagy társaságról. Az állatokkal és környezetükkel való rendszeres és közvetlen érintkezés több lehetőséget ad arra, hogy a betegségek átterjedjenek az állatok és az emberek között.

A Földön komoly változások történtek az éghajlat és a földhasználat terén. Míg az előbbi részben, addig az utóbbi teljes egészében emberi tevékenység, mint például az erdőirtások és az intenzív mezőgazdaság következménye. A környezeti feltételek megváltoztatása és az élőhelyek megzavarása új lehetőségeket nyújthatnak a betegségek állatokra átterjedésére.

Az emberek, állatok és állati termékek mozgása a nemzetközi utazás és kereskedelem miatt megnőtt. Ennek eredményeképpen az országhatárok többé már nem állják útját a betegségeknek, amelyek így a világ minden táján gyorsan elharapózhatnak.
Ezek a változások a már ismert vagy újonnan megjelenő, állatról emberre terjedő betegségek (zoonózisok) szétszóródásához vezettek. Ilyenek például a veszettség, a szalmonellafertőzés, a nyugat-nílusi vírusfertőzés, a Q-láz (Coxiella burnetii), az anthrax, a brucellózis, a Lyme-kór, az ebola.

Az állatok is fogékonyak lehetnek bizonyos emberi betegségekkel és környezeti ártalmakkal szemben. Emiatt néha korai figyelmeztető jelként szolgálhatnak emberi betegségek megjelenésére. A madarak például gyakran elpusztulnak a nyugat-nílusi vírustól, mielőtt az ugyanazon a területen élő emberek megbetegednének a vírusfertőzésben.

\section{MELYEK A GYAKORI „EGY AZ EGÉSZSÉG"- PROBLÉMÁK?}

$A z$ "Egy az egészség" kérdéskörébe tartoznak a zoonózisok, az antimikrobiális rezisztencia (AMR, mikrobák, azaz baktériumok, vírusok, gombák elleni szerekkel szembeni ellenállóképesség öszszefoglaló neve), az élelmiszerbiztonság, az állatok által terjesztett betegségek, a környezetszennyezés, valamint az emberek, az állatok és a környezet által közösen okozott egyéb egészségkockázatok. Még a krónikus betegségek, a mentális egészség, a sérülések, a munkahelyi egészség és a nem fertőző betegségek területén is hasznot hozhat az "Egy az egészség"-megközelítés, amely elősegíti a tudományágak és ágazatok közötti együttmúködést. 
1. ábra: Az „Egy az egészség"-koncepció illusztrálása

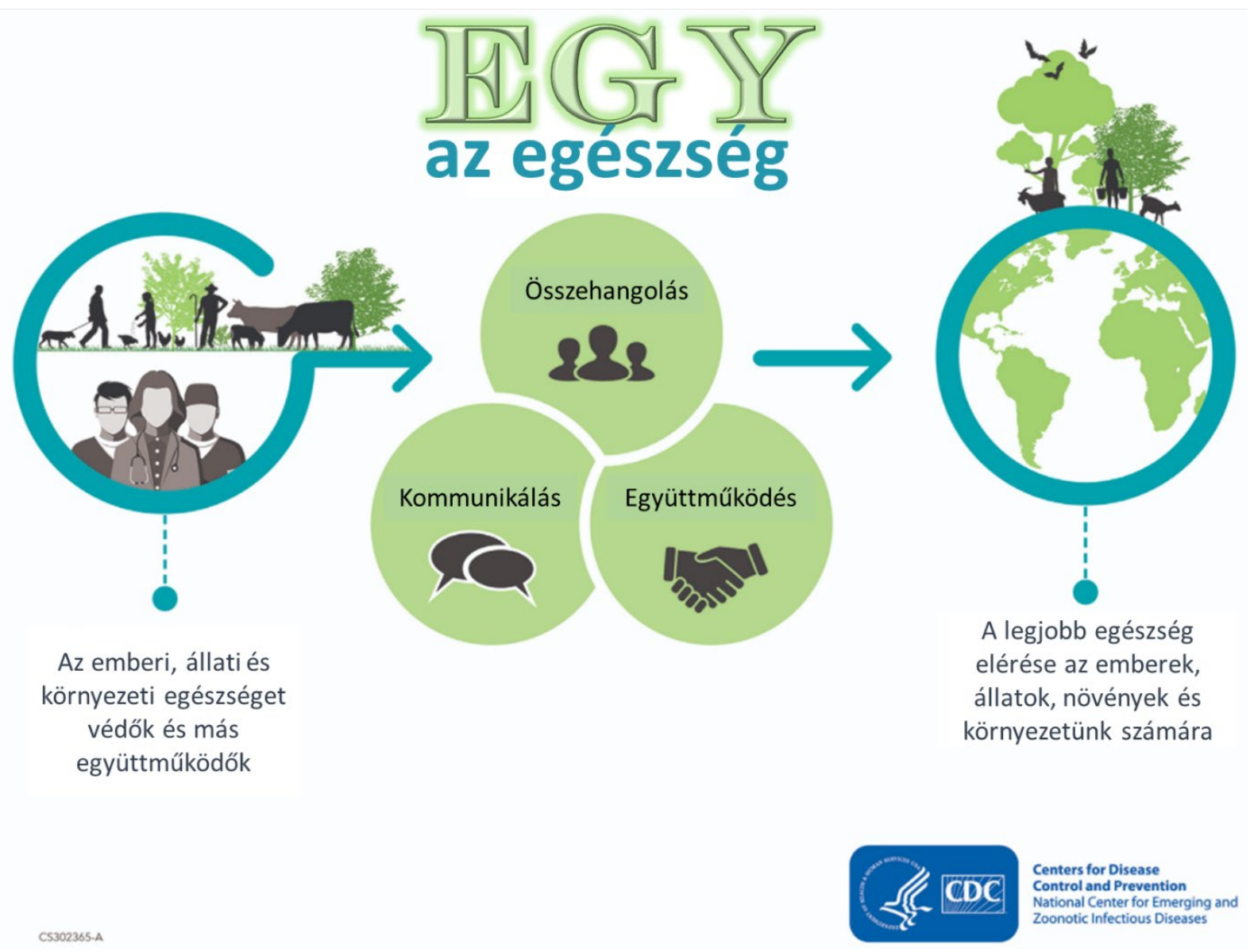

Forrás: az eredeti magyar szöveggel

HOGYAN MŰKÖDIK AZ „EGY AZ EGÉSZSÉG"MEGKÖZELÍTÉS?

Az „Egy az egészség" egyre inkább elismert az Egyesült Államokban és világszerte, mint az ember-állat-környezet határterületen jelentkező egészségproblémák, köztük a zoonózisok elleni küzdelem hatékony módja. A CDC (Centers for Disease Control and Prevention) az "Egy az egészség"-megközelítést alkalmazza az emberi, állati, környezeti egészség- és más releváns tudományágak és ágazatok szakértőinek bevonásával a népegészségügyi veszélyek megfigyelésében és visszaszorításában, valamint annak vizsgálatában, hogy a betegségek hogyan terjednek az emberek, állatok, növények és a környezet között.

A sikeres népegészségügyi beavatkozásokhoz az emberi, állati és környezet-egészségügyi partnerek együttmúködésére van szükség. A humán- egészségügy (orvosok, ápolók, népegészségügyi szakemberek, epidemiológusok), az állategészségügy (állatorvosok, segítő szakemberek, mezőgazdasági dolgozók), a környezetvédelem (ökológusok, vadon élő állatok szakértői) és más szakterületek szakembereinek kell kommunikálniuk, együttműködniük és összehangolniuk a tevékenységeiket. Az "Egy az egészség"-megközelítés további fontos szereplői lehetnek a bủnüldöző szervek, a politikai döntéshozók, a mezőgazdaság, a közösségek és még a kedvtelésből tartott állatok tulajdonosai is. Egyetlen személy, szervezet vagy ágazat sem képes egyedül kezelni az állat-ember-környezet határterületén felmerülő problémákat.

$A z$ összes ágazat közötti együttműködés előmozdításával az „Egy az egészség"-megközelítés a legjobb egészséget érheti el az emberek, az állatok és a növények számára egy közös környezetben. 


\section{TANULSÁGOK A HAZAI SZAKEMBEREK SZÁMÁRA}

A nemzetközi szakirodalomban egyre inkább elfogadottá vált "Egy az egészség" megközelítést a magyar szakembereknek is figyelembe kellene venniük mind a népegészségügy, mind a környezetvédelem és a klímaváltozás területén. A Föld élettelen és élő világa egyetlen nagy és összetett rendszert alkot, elemei egymásra hatással vannak. Ennek a komplexitásnak jól felismerhető jeleit láthatjuk egyre gyakrabban, mint például a felmelegedés következtében délről Európába bevándorló szúnyogok által terjesztett trópusi betegségek magyarországi megjelenése, vagy a vadállatokról emberre terjedő SARS-CoV-2 vírus okozta világjárvány. A hazai lakosság egészségének javítására irányuló tevékenységek tervezésekor és megvalósításakor nem hagyható figyelmen kívül az ember és környezete közötti interakció.

Információk a szerzőről:

Vitrai József, független népegészségügyi szakértő, vitrai.jozsef@gmail.com 